\title{
TINGKAT PARTISIPASI PUBLIK MELALUI PEMANFAATAN MEDIA LAPOR DI KOTA BANDUNG
}

\author{
Nur Atnan dan Ayub Ilfandy Imran \\ Program Studi Ilmu Komunikasi, Fakultas Komunikasi dan Bisnis, \\ Telkom University, Bandung. \\ E-mail: nuratnan@telkomuniversity.ac.id
}

\begin{abstract}
ABSTRAK.
Layanan Aspirasi Pengaduan Online Rakyat (LAPOR) merupakan aplikasi media sosial yang digunakan di Kota Bandung sejak November 2013 untuk mendorong partisipasi publik dalam pembangunan. Dalam konteks kehidupan demokrasi, pemanfaatan LAPOR dapat membantu pemerintah untuk mendengarkan aspirasi rakyat. Tujuan dari penelitian ini adalah untuk mengetahui dan menganalisis seberapa besar tingkat partisipasi masyarakat Kota Bandung dalam pemanfaatan LAPOR, faktor-faktor yang mempengaruhi partisipasi masyarakat dalam penggunaan LAPOR, dan bagaimana pendapat masyarakat tentang kinerja Pemerintah Kota Bandung dalam pengelolaan LAPOR. Penelitian ini menggunakan mix method, yakni perpaduan antara metode kuantitatif dan metode kualitatif. Pengolahan data dilakukan dengan analisa kuantitatif dan kualitatif. Hasil penelitian menunjukkan bahwa masyarakat Kota Bandung masih banyak yang belum berpartisipasi menggunakan aplikasi LAPOR, faktor dominan pendorong partisipasi penggunaan LAPOR karena kemudahan penggunaan aplikasinya bukan karena manfaatnya, dan responden juga menilai kinerja Operator LAPOR sudah cukup baik.
\end{abstract}

Kata Kunci: Tingkat Partisipasi; Aspirasi; Pemanfaatan LAPOR; Kinerja.

\section{PUBLIC PARTICIPATION THROUGH “LAPOR” UTILIZATION IN BANDUNG CITY}

\begin{abstract}
.
Community's Complaint and Aspiration Online Service (LAPOR) is an online application introduced by Bandung City since November 2013 to encourage public participation in the development process. In the context of democratic life, the application of LAPOR can help the government in listening to people's aspirations. This research is aimed to examine and analyze the level of public participation through the usage of LAPOR, factors that influence public participation in the usage of LAPOR, including public opinion on the performance of Bandung's government in managing LAPOR. Mixed method, both qualitative and quantitative, are used in this research, including in data processing. Research shows that most of Bandung inhabitants have never participate in using LAPOR application. With the low level of the users, the dominant factor that encourage public participation in using LAPOR is due to the convenience of the application instead of its advantages. Respondents also agree that the performance of LAPOR operators is considered good.
\end{abstract}

Key words: Participation Level; Aspiration; LAPOR Utilization; Performance.

\section{PENDAHULUAN}

Perkembangan Teknologi Informasi dan Komunikasi yang terjadi sejak abad ke-20 telah melahirkan media baru dalam proses komunikasi. Munculnya media baru mengakibatkan peralihan dari dunia analog ke dunia digital. Komponen media baru tersebut meliputi handphone, internet dan komputer. Munculnya media baru ini mengakibatkan proses komunikasi bisa terjadi dengan cepat, luas dan interaktif.

Dalam perkembangannya, media baru juga diaplikasikan di dunia pemerintahan. Salah satu program pemerintah yang menggunakan media baru terutama internet adalah LAPOR (Layanan Aspirasi Pengaduan Online Rakyat). Program ini merupakan singkatan dari Layanan Aspirasi Pengaduan Online Rakyat. Program ini dikembangkan oleh UKP4 (Unit Kerja Presiden Bidang Pengawasan dan Pengendalian Pembangunan) pada masa pemerintahan SBY. Saat ini program LAPOR dikendalikan oleh Kantor Staf Kepresidenan (KSK) yang menggantikan fungsi UKP4 (Unit Kerja Presiden Bidang Pengawasan dan Pengendalian Pembangunan) di masa pemerintahan Joko Widodo.

Pemerintah Kota Bandung adalah salah satu yang mengunakan program LAPOR. Program 
ini sesungguhnya sudah diawali terlebihdahulu di Provinsi DKI Jakarta. Pemerintah Kota Bandung sendiri menginisiasi adopsi LAPOR pada tahun 2012. Semenjak Ridwal Kamil dinyatakan sebagai pemenang dalam Pemilihan Walikota Bandung oleh KPUD Kota Bandung, proses penjajakan ke UKP4 mulai dilakukan, hingga akhirnya pada bulan November 2013 terjadi penandatanganan $\mathrm{MoU}$ antara UKP4 dengan Pemerintah Kota Bandung dalam rangkah adopsi LAPOR.

LAPOR diadopsi oleh Pemerintah Kota Bandung dalam rangkah mewujudkan slogan Bandung Juara. Untuk mewujudkan hal ini, partisipasi luas dari masyarakat bandung sangat diperlukan. LAPOR mengakomodasi masyarakat untuk berpartisipasi dalam pembangunan dan pengawasan layanan publik dengan mudah. Penggunaan LAPOR diharapkan mendorong masyarakat untuk peduli dan aktif dalam proses pembangunan serta memberikan penilaian terhadap kinerja Pemerintah Kota dalam memberikan pelayanan publik.

LAPOR merupakan sarana aspirasi dan pengaduan yang berbasis media sosial. Dalam konteks demokrasi, LAPOR merupakan instrumen untuk mendorong partisipasi publik melalui teknologi berupa aplikasi. Aplikasi ini merupakan yang pertama di Indonesia. Untuk memanfaatkan LAPOR dalam menyampaikan aspirasi, bertanya atau menyampaikan keluhan tentang kinerja pemerintah, masyarakat cukup mengakses situs LAPOR di www.lapor.ukp. go.id. Terdapat tiga cara yang bisa dilakukan melalui website, yaitu bergabung melalui akun facebook, twitter atau registrasi terlebihdahulu. Namun Akses lebih mudah bila dilakukan dengan SMS ke 1708 dengan format BDG $<$ spasi>isi aduan.

Di Kota Bandung sendiri, Dinas yang mengelola LAPOR adalah Dinas Informasi dan Komunikasi (DISKOMINFO) Kota Bandung. Terdapat dua peran strategis dari DISKOMINFO dalam mengelola LAPOR, yaitu (1) Mensosialisasikan LAPOR ke semua masyarakat Kota Bandung, (2) Berkoordinasi dengan semua Dinas/ Badan di Pemerintahan Kota Bandung agar menyiapkan minimal satu orang pegawai untuk menindaklanjuti pengaduan dari masyarakat serta bekerjasama dalam menindaklanjuti setiap pengaduan masyarakat.

Program LAPOR akan berhasil jika dua peran strategis DISKOMINFO dijalankan dengan baik. Dalam peran strategis yang pertama,
DISKOMINFO Kota Bandung harus mampu mengenalkan dan mendorong masyarakat untuk menggunakan program LAPOR. oleh karena itu DISKOMINFO harus melakukan sosialisasi kepada seluruh lapisan masyarakat tentang program LAPOR.

TimLAPORDISKOMINFO menggunakan beberapa media dalam rangkah sosialisasi LAPOR. Beberapa media tersebut adalah face to face communication melalui penyuluhan di kantor kecamatan, di Auditorium Rosada, serta di beberapa Universitas melalui komunitas tertentu. Media lain yang digunakan adalah Radio, Televisi, Spanduk, dan Banner yang di pasang di Kantorkantor Dinas/Badan, Kecamatan dan Kelurahan sekota Bandung.

Setelah kegiatan sosialisasi, seharusnya masyarakat sudah mengetahui dan diharapkan memanfaatkan fasilitas LAPOR untuk menyampaikan aspirasinya dalam kerangka perbaikan layanan publik di Kota Bandung. Namun jika kita mengacu pada jumlah data pengaduan yang masuk di sistem LAPOR pada tahun 2015 belum mengindikasikan harapan tersebut. Masih sedikit masyarakat yang berpartisipasi dalam memanfaatkan media ini. Data per 8 Juni 2015, jumlah total pengaduan 6.975. Dari total pengaduan tersebut, 90\% sudah diselesaikan, $7 \%$ masih dalam proses dan 3\% belum ada tindak lanjut (LAPOR, 2015).

Jika dibandingkan dengan jumlah penduduk Kota Bandung, dimana total jumlah penduduk sebesar 2.483.977 jiwa (BPS Kota Bandung, 2014), jumlah masyarakat yang aktif berpartisipasi melaporkan masalah-masalah Kota Bandung masih sangat sedikit, yakni hanya $0,3 \%$. Data ini jika asumsinya setiap laporan berasal dari orang yang berbeda. Faktanya, laporan terkadang berasal dari orang yang sama. Artinya, jumlah masyarakat Kota Bandung yang memanfaatkan LAPOR masih di bawah 3\%.

Fenomena diatas menunjukkan bahwa program LAPOR belum termanfaatkan dengan baik oleh masyarakat Kota Bandung. Padahal beberapa kondisi seharusnya mendorong masyarakat untuk menggunakanan aplikasi ini. Kota Bandung merupakan pengguna handphone, facebook dan twitter terbayak di Indonesia, bahkan untuk twitter merupakan pengguna terbesar ke 6 di dunia (Semiocast, 2012). Hal ini menjadi menarik dan mendorong peneliti untuk menganalisis lebih dalam secara ilmiah tentang pengetahuan dan tingkat penggunaan LAPOR oleh masyarakat di Kota Bandung. 
Berdasarkan latar belakang diatas, terdapat beberapa permasalahan yang muncul dan akan dianalisis dalam penelitian ini, yaitu (1) Bagaimana tingkat partisipasi masyarakat dalam penggunaan LAPOR (2) Faktor-faktor yang mempengaruhi partisipasi masyarakat dalam menyampaikan aspirasi dalam perbaikan layanan publik di Kota Bandung melalui LAPOR, dan (3) Bagaimana pendapat masyarakat Kota Bandung terhadap kinerja Pemerintah Kota Bandung dalam merespon pengaduan masyarakat melalui LAPOR.

Terdapat beberapa penelitian serupa yang menjadi acuan pembanding dalam penelitian ini, diantaranya penelitian yang dilakukan oleh Dian Purworini (2014) yang meneliti tentang Model Informasi Publik Di Era Media Sosial: Kajian Grounded Teori Di Pemda Sukoharjo. Penelitian ini dilakukan di Pemerintah Daerah Sukoharjo pada tahun 2014. Penelitian ini bertujuan untuk mempelajari model komunikasi yang dilakukan oleh Humas Pemda Sukoharjo melalui pemanfaatan media sosial.

Penelitian lain dilakukan oleh Wasisto Raharjo Jati (2016) dengan judul Cyberspace, Internet, dan Ruang Publik Baru; Aktivisme Online Politik Kelas Menengah Indonesia. Penelitian ini berlangsung di Indonesia dengan metode kualitatif. Penelitian ini ditujukan untuk menganalisis mengenai cyberspace sebagai ruang publik baru bagi kelas menengah di Indonesia.

Penelitian sejenis juga dilakukan oleh Herri Setiawan dan Puwo Santoso (2013) dengan judul Model Optimalisasi Peluang Pemanfaatan Media Jejaring Sosial dalam Implementasi E-Governance di Indonesia. Penelitian ini hendak menjawab bagaimanakah pola interaksi pemerintah dan masyarakat yang dapat mengoptimalkan penggunaan media sosial.

Tiga penelitian yang dipaparkan di atas berfokuskan kepada penggunaan media sosial oleh pemerintah dalam membangun komunikasi dengan masyarakat. Sementara peneliti fokus pada penggunaan aplikasi khusus yang mengkombinasikan media sosial, website, dan SMS dalam menyerap aspirasi publik untuk perbaikan layanan.

Perbedaan antara penelitian media LAPOR dan media lain yang dibahas di penelitian sebelum nya adalah LAPOR merupakan jenis teknologi yang berbeda. Teknologi ini diciptakan pemerintah untuk kepentingan kesejahteraan masyarakat. Teknologi ini tidak bersifat 'entertaining' yang mungkin menjadi penyebab kurangnya minat dan penggunaan dari masyarakat. Akan tetapi, teknologi LAPOR tergolong mudah untuk digunakan dan sangat bermanfaat untuk kepentingan masyarakat. Dua faktor ini merupakan faktor penting yang ditekankan oleh TAM dalam proses pengadopsian sebuah teknologi. Oleh karena itu peneliti ingin memahami peran kedua faktor ini terhadap penggunaan media LAPOR.

Dalam menganalisis fenomena dalam penelitian ini, peneliti menggunakan teori Technological Acceptance Model (TAM). Teori ini dapat digunakan untuk melihat tingkat partisipasi publik dalam penggunaan teknologi. Teori ini pertama kali dikenalkan oleh Davis (1986). Teori ini dikembangkan dari Theory of Reasoned Action (TRA) oleh Ajzen dan Fishbein (1980). Teori ini menjadi relevan karena LAPOR merupakan salah satu teknologi informasi. Model penerimaan teknologi (technology acceptance model atau TAM) merupakan suatu model penerimaan sistem teknologi informasi yang akan digunakan oleh pemakai. Model penerimaan teknologi atau TAM dikembangankan oleh Davis, et.al. (1989) berdasarkan model TRA.

Model TRA dapat diterapkan karena keputusan yang dilakukan oleh individu untuk menerima suatu teknologi sistem informasi merupakan tindakan sadar yang dapat dijelaskan dan diprediksi oleh minat perilakunya. TAM menambahkan dua konstruk untama ke dalam model TRA. Dua konstruk utama ini adalah kegunaan persepsian (perceived usefulnes) dan kemudahan penggunaan persepsian (perceived ease of use). TAM beragumentasi bahwa penerimaan individual terhadap sistem teknologi informasi ditentukan oleh dua konstruk tersebut.

Kegunaan persepsian (perceived usefullness) dan kemudahan penggunaan persepsian (perceived ease of use) keduannya mempunyai pengaruh ke minat perilaku (behavioral intention). Pemakaian teknologi akan mempunyai minat menggunakan teknologi (minat perilaku) jika merasa sistem teknologi bermanfaat dan mudah digunakan.

Kegunaan persepsian (perceived usefullness) juga mempengaruhi kemudahan penggunaan persepsian (perceived ease of use) tetapi tidak sebaliknya. pemakai sistem akan menggunakan sistem jika sistem bermanfaat baik sistem itu mudah digunakan atau tidak mudah digunakan. Sistem yang sulit digunakan akan tetap digunakan jika pemakai merasa bahwa sistem masih berguna. 
Karena TAM dimaksudkan untuk penggunaan teknologi, maka perilaku (behavior) di TAM dimaksudkan sebagai perilaku menggunakan teknologi. Oleh karena itu TAM juga banyak dituliskan lebih spesifik pada penggunaan teknologi sebagai berikut ini:

Technology acceptance model (TAM) yang pertama yang belum dimodifikasi menggunakan lima konstruk utama. Kelima konstruk ini adalah sebagai berikut ini.

1. Kegunaan Persepsian

Sejauh mana seseorang percaya bahwa menggunakan suatu teknologi akan meningkatkan kinerja pekerjaanya. Merupakan suatu kepercayaan dalam mengambil keputusan, seseorang merasa percaya bahwa teknologi berguna maka dia akan menggunakannya.

2. Kemudahan Penggunaan Persepsian

Didefinisikan sejauh mana seseorang percaya bahwa menggunakan teknologi akan bebas dari usaha. Jadi apabila seseorang percaya bahwa teknologi tersebut mudah digunakan maka seseorang tersebut akan menggunakannya bahkan sebaliknya.

3. Sikap Terhadap Perilaku

Perasaan positif atau negatif dari seseorang ketikamenilaiteknologitersebut, didefinisikan juga oleh Mathieson (1991) sikap disini dapat didefinisikan sebagai evaluasi pemakaian tentang ketertarikan menggunakan system.

4. Minat Menggunakan Teknologi

Minat perilaku adalah suatu keinginan seseorang untuk menggunakan teknologi, seseorang akan menggunakan teknologi apabila mempunyai keinginan atau minat untuk menggunakannya.

5. Penggunaan Teknologi

Penggunaan di definisikan sebagai tindakan yang dilakukan oleh seseorang, dimana seseorang tersebut menggunakan teknologi diukur dengan jumlah waktu yang digunakan untuk berinteraksi dengan teknologi tersebut, dan frekuensi penggunaanya.

\section{METODE}

Penelitian ini menggunakan mix method sebagai metode dasarnya dengan dominasi pendekatan kuantitatif. Mix method dipahami sebagai perpaduan antara metode kuantitatif dan metode kualitatif. Pengolahan data dalam penelitian ini dilakukan dengan analisa kuantitatif dan kualitatif berdasarkan permasalahan-permasalahan yang ada. (Creswell, 2010). Jenis metode kuantitatif dalam penelitian ini adalah deskriptif yang dialukan dengan survey, yakni penelitian yang pengambilan datanya diperoleh dari sampel terhadap suatu populasi tertentu dan umumnya menggunakan kuesioner. Jenis survey yang digunakan adalah cross sectional survey, yakni data hanya dikumpulkan dalam suatu waktu tertentu untuk menggambarkan kondisi populasi (Purwanto dan Sulistyastuti, 2007).

Penelitian secara kuantitatif ini digunakan untukmengetahuibeberapahal,yaitu(1)Tingkat partisipasi masyarakat dalam penggunaan LAPOR (2) Faktor-faktor yang mempengaruhi partisipasi masyarakat dalam menyampaikan aspirasi dalam perbaikan layanan publik di Kota Bandung melalui LAPOR, dan (3) Pendapat masyarakat Kota Bandung terhadap kinerja Pemerintah Kota Bandung dalam merespon pengaduan masyarakat melalui LAPOR. Sedangkan Metode kualitatif dalam penelitian ini dilakukan secara deskriptif analisis yaitu mengumpulkan fakta dan menguraikan secara menyeluruh dan teliti sesuai dengan persoalan yang akan diselesaikan (Bungin, 2010). Metode kualitatif dalam penelitian ini bertujuan untuk mengetahui mengapa hasil penelitian secara kuantitatif terjadi.

Populasi dalam penelitian adalah masyarakat kota Bandung yang sudah dewasa dan bisa menggunakan handphone, facebook, dan twitter. Jumlah penduduk/masyarakat Kota Bandung yang usianya $\geq 15$ tahun dan sekaligus menjadi jumlah populasi dalam penelitian ini adalah 1.873.856 orang (BPS Kota Bandung, 2014).

Untuk mengetahui persentase jumlah masyarakat yang mengetahui program LAPOR, menggunakan teknik sampling probabilitas jenis cluster sampling. Jumlah sampelnya dihitung dengan menggunakan rumus slovin, yaitu $\mathrm{n}$ $=\frac{N}{1+N e^{2}}$. Dengan mengacu pada rumus tersebut dengan nilai taraf signifikansi 5\%, maka maksimal jumlah sampelnya adalah 399,9 orang. Namun karena kondisi masyarakat kota Bandung yang cukup homogen, maka peneliti memutuskan jumlah sampelnya sebanyak 100 orang yang berasal dari lima wilayah yaitu Bandung Utara, Bandung Selatan, Bandung Barat, Bandung Timur dan Bandung Tengah.

Untuk mengetahui tingkat partisipasi masyarakat dalam penggunaan LAPOR, faktorfaktor dominan yang menyebabkan masyarakat menggunakan LAPOR serta pendapat masyarakat tentang kinerja Pemerintah Kota Bandung dalam merespon aduan melalui 
LAPOR menggunakan teknik sampling non probality sampling jenis purposive. Peneliti akan menggunakan jumlah sampel sebanyak 50 orang yang pernah menggunakan LAPOR.

Penelitian ini hanya memiliki satu variabel dan beberapa Indikator mengacu pada beberapa teori dan konsep yang digunakan dalam penelitian ini. Variabel dan Indikator dalam penelitian ini dapat terlihat dalam tabel berikut :

Tabel 1. Variabel dan Indikator Penelitian

\begin{tabular}{lrl}
\hline \multicolumn{1}{c}{ Variabel } & \multicolumn{1}{c}{ Indikator } \\
\hline Penggunaan & (1) $\begin{array}{l}\text { Mengetahui atau Tidak } \\
\text { Media LAPOR }\end{array}$ & $\begin{array}{l}\text { Mengetahui LAPOR } \\
\text { Tingkat Pengetahuan } \\
\text { Masyarakat }\end{array}$ \\
& (3) Manfaat LAPOR \\
& (4) Kemudahan Penggunaan \\
& LAPOR \\
& (5) $\begin{array}{l}\text { Pendapat Masyarakat } \\
\text { Tentang Kinerja Pemkot } \\
\text { dalam Merespon Aduan }\end{array}$ \\
& Sumber : Diolah oleh Peneliti, 2016.
\end{tabular}

Informan digunakan hanya untuk menganalisis mengapa temuan kuantitatifnya berada dalam kondisi tertentu. Penggunaan informan dimaksudkan untuk menganalisis temuantemuan penelitian secara kuantitatif melalui indepth interview dengan beberapa orang yang mengetahui dan mengamati palikasi LAPOR. Informan dalam penelitian ini terdiri dari beberapa unsur, yaitu (1) Pengelola LAPOR dari Diskominfo Kota Bandung, (2) Anggota DPRD Kota Bandung khususnya Komisi Pemerintahan, (3) Petugas LAPOR di SKPD, (4) Tokoh masyarakat dalam struktur RW/RT.

Teknik analisis data mengacu pada permasalahan dalam penelitian ini. Karena penelitian ini menggunakan mixed method, maka teknik analisis yang digunakan juga dua, yaitu teknik analisis kuantitatif dan teknik analisis kualitatif. Analisis dilakukan berurutan, yakni terlebih dahulu data kuantitatif yang dianalisis, baru kemudian data kualitatif yang diperoleh dari hasil indepth interview.

Analisis kuantitatif digunakan untuk mengetahuipersentasipartisipasimasyarakatdalam penggunaan LAPOR; tingkat pengetahuannya tentang LAPOR masuk dalam kategroi apa, apakah tinggi, sedang atau rendah; diantara beberapa faktor yang mempengaruhi penggunaan LAPOR, faktor apa yang paling dominan yang mempengaruhinya; dan bagaimana pendapat masyarakat Kota Bandung atas kinerja Pemerintah Kota Bandung dalam merespon aduan melalui LAPOR, apakah baik, cukup, atau masih kurang.

Jenis teknis analisis kuantitatifnya adalah analisis deskriptif, yaitu menggambarkan karakteristik dari populasi atau fenomena yang sedang diteliti. Analisis bertujuan untuk memprediksi atau mengestimasi keadaaan tertentu. Untuk menggambarkan karakteristik dari sampel/populasi yang sedang diteliti, maka hanya dilihat frekuensinya saja.

Untuk mengelompokkan kategori, apakah tinggi-sedang-rendah atau baik-cukup-kurang, maka terlebih dahulu ditentukan intervalnya. Penentuan interval menggunakan rumus interval $=$. Setelah interval diketahui maka dapat ditentukan rentang skor perkategori.

Untuk analisis kualitatif menggunakan model Miles and Huberman (1984). Dengan mengacu pada model tersebut, analisis data dilakukan secara interaktif dan berlangsung secara terus menerus sampai tuntas. Aktivitas dalam analisis data yaitu data reduction, data display, dan conclusion drawing/verification

\section{HASIL PENELITIAN}

Berdasarkan rumusan masalah, terdapat tiga hal yang dilihat, yaitu (1) tingkat partisipasi penggunaan LAPOR oleh masyarakat di Kota Bandung, (2) faktor-faktor yang mempengaruhi partisipasi masyarakat dalam penggunaan aplikasi LAPOR dan (3) pendapat masyarakat tentang kinerja Operator LAPOR. Secara lebih detail hasil penelitiannya akan diuraikan lebih rinci sebagai berikut:

\section{A. Tingkat Partisipasi Penggunaan LAPOR oleh Masyarakat di Kota Bandung}

Terdapat beberapa hal yang diuraikan pada bagian ini, yaitu (1) pengetahuan dan partisipasi penggunaan LAPOR, (2) sumber pengetahuan, (3) frekuensi partisipasi penggunaan LAPOR, (4) waktu menggunakan, (5) jenis keluhan masyarakat, dan (6) tingkat pengetahuan masyarakat tentang LAPOR.

Responden yang mengetahui LAPOR cukup besar, yakni lebih dari 69,3\%, sisanya sekitar 36,1\% tidak mengetahui LAPOR. Dari sejumlah responden yang mengetahui LAPOR, hanya $35 \%$ yang berpartisipasi meng-gunakannya. Dari sejumlah responden, yang tidak berpartisipasi menggunakan LAPOR sebesar 65\%. 


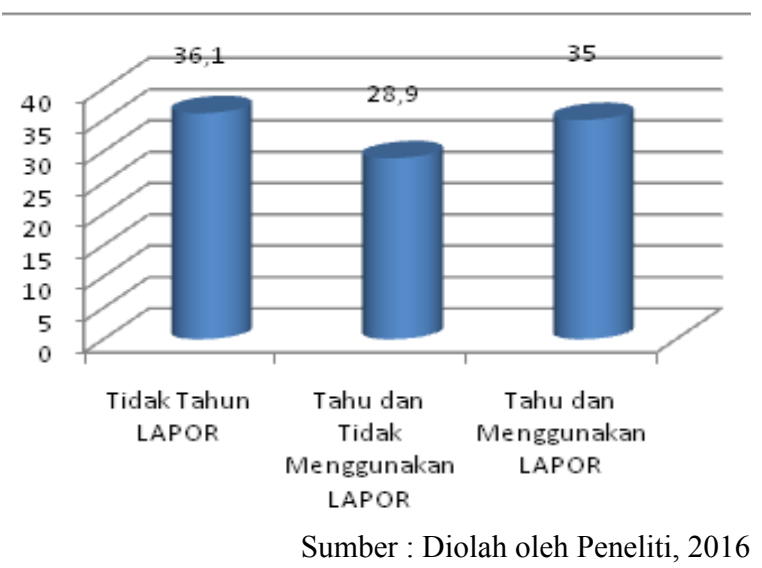

Gambar 1. Pengetahuan dan Partisipasi Penggunaan LAPOR (dalam \%)
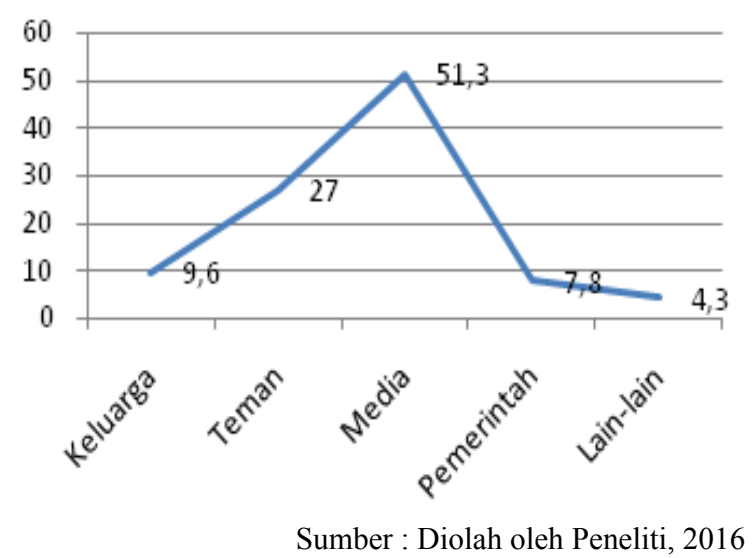

Gambar 2. Sumber Pengetahuan LAPOR

Responden mengetahui LAPOR kebanyakan dari media, yaitu 51\%. Selain itu, banyak juga responden yang mengetahuinya dari teman. Sedikit responden yang mengetahui LAPOR dari sosialisasi pemerintah, yakni hanya 7,8\%.

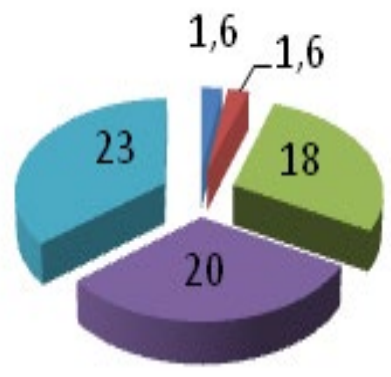

- Sangat Sering

sering

Kadang-kadang

Jarang

- Sangat Jarang

Sumber : Diolah oleh Peneliti, 2016

Gambar 3. Frekuensi Partisipasi Penggunaan LAPOR (dalam \%)

Mayoritas responden mengatakan jarang menggunakan LAPOR. Selain itu, cukup banyak juga yang mengatakan sangat jarang. Terdapat juga responden yang menyatakan kadang-kadang. Responden yang menyatakan sering dan sangat sering sangat sedikit, karena masing-masing kurang dari $2 \%$.

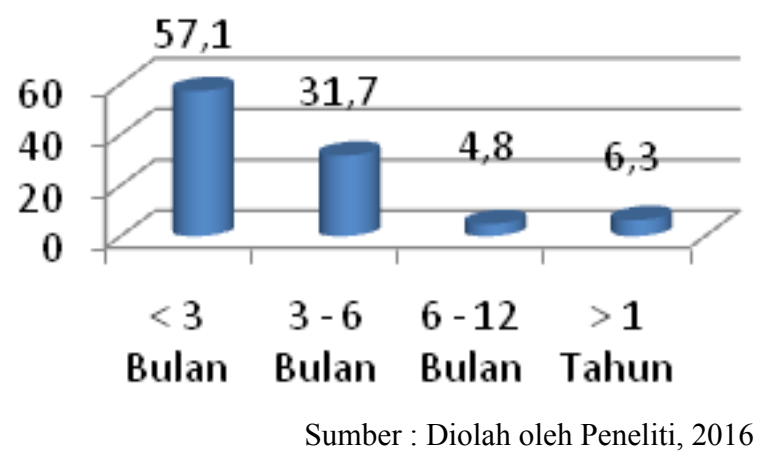

Gambar 4. Waktu Menggunakan LAPOR (dalam \%)

Mayoritas responden menyatakan bahwa kurang dari tiga bulan menggunakan LAPOR yakni sebanyak 57,1\%. Hanya sedikit responden yang menggunakan LAPOR pada rentang 6-12 tahun yakni $4,8 \%$.

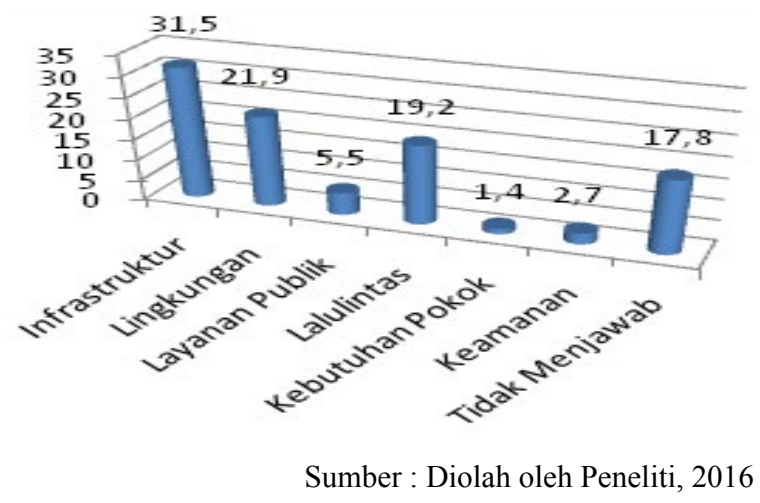

Gambar 5. Jenis Keluhan Masyarakat pada LAPOR (dalam \%)

Keluhan responden kebanyakan soal infrastruktur. Infrastruktur itu terutama terkait jalan rusak dan fasilitas umum. Selain soal infrastruktur, keluhan responden juga banyak tentang lingkungan terutama terkait dengan sampah. Hal lain yang menjadi aduan adalah soal lalu lintas terutama tentang kemacetan.

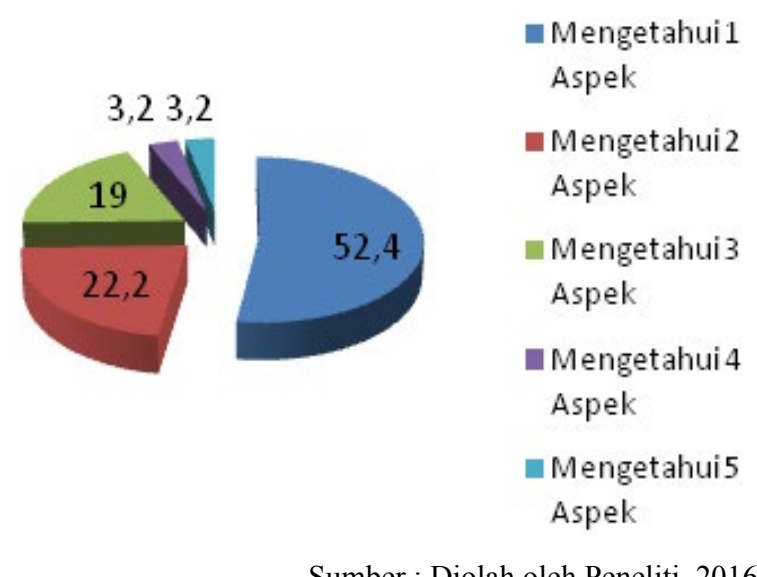

Gambar 6. Tingkat Pengetahuan Masyarakat tentang LAPOR (dalam \%) 
Berdasarkan diagram diatas, tingkat pengetahuan responden tentang LAPOR rendah karena hanya mengetahui satu aspek saja. Pengetahuan responden dikatakan tinggi apabila mengetahui lima aspek LAPOR. Lima aspek tersebut meliputi (1) LAPOR adalah aplikasi khusus yang dapat digunakan untuk menyampaikan atau melaporkan keluhan/kritik terkait dengan layanan publik di Kota Bandung, (2) LAPOR dapat diakses melalui facebook, (3) LAPOR dapat diakses melalui twitter, (4) LAPOR dapat diakses melalui website dengan ID khusus melalui proses registrasi terlebih dahulu, dan (5) LAPOR dapat diakses melalui HP dengan cara SMS pengaduan dan dikirim ke 1708.

\section{B. Faktor-faktor yang Mempengaruhi Parti- sipasi Masyarakat dalam Penggunaan LAPOR}

Terdapat empat faktor yang mempengaruhi penggunaan LAPOR oleh masyarakat di Kota Bandung, yaitu (1) kemudahan penggunaan, (2) manfaat penggunaan LAPOR, (3) sikap terhadap LAPOR, dan (4) penggunaan LAPOR. Berikut akan diuraikan tanggapan responden terhadap empat faktor tersebut, yaitu:

\section{Kemudahan Penggunaan Program LAPOR}

Bagianinimengevaluasitingkatkemudahan penggunaan program LAPOR bagi masyarakat Bandung. Penelitian ini melibatkan 63 orang masyarakat yang menggunakan program LAPOR. Tabel 2 menunjukkan hasil analisa untuk tingkat kemudahan penggunaan program LAPOR yang diukur dengan menggunakan 5 pernyataan. Setiap pernyataan diukur dengan 5 tingkat persetujuan, berdasarkan skala $1=$ sangat tidak setuju, $2=$ tidak setuju, $3=$ netral, $4=$ setuju, $5=$ sangat setuju.

Hasilanalisamenunjukkanbahwapengguna program LAPOR mempunyai tanggapan yang positif mengenai kemudahaan penggunaan program ini. Pengguna berpendapat bahwa "cara penggunaan aplikasi LAPOR mudah untuk diikuti" dengan rata-rata paling tinggi yaitu 3.57. Untuk selanjutnya terkait dengan pendapat tentang "aplikasi LAPOR sangat mudah untuk digunakan" memperoleh nilai rata-rata 3.55 , "saya akan tetap menggunakan aplikasi LAPOR karena mudah untuk digunakan" mendapat nilai rata-rata 3.38, "saya belum menemui kesulitan berarti selama menggunakan aplikasi LAPOR" memperoleh rata-rata 3.34, dan "informasi mengenai aplikasi LAPOR mudah untuk dicari" mendapatkan nilai rata-rata paling rendah 3.30.
Secara keseluruhan, pengguna program LAPOR berpendapat bahwa program ini mudah untuk di gunakan dengan rata-rata keseluruhan 3.43.

Tabel 2. Kemudahan Penggunaan Program LAPOR

\begin{tabular}{|c|c|c|c|c|c|c|c|}
\hline \multirow[t]{2}{*}{ No } & \multirow{2}{*}{$\begin{array}{l}\text { Kemudahan } \\
\text { Penggunaan }\end{array}$} & \multicolumn{5}{|c|}{ Tingkat Persetujuan } & \multirow{2}{*}{$\begin{array}{c}\text { Rata- } \\
\text { rata }\end{array}$} \\
\hline & & 1 & 2 & 3 & 4 & 5 & \\
\hline 1 & $\begin{array}{l}\text { Aplikasi } \\
\text { LAPOR } \\
\text { sangat } \\
\text { mudah untuk } \\
\text { digunakan. }\end{array}$ & 0 & 2 & 29 & 27 & 5 & 3.55 \\
\hline 2 & $\begin{array}{l}\text { Informasi } \\
\text { mengenai } \\
\text { aplikasi } \\
\text { LAPOR } \\
\text { mudah untuk } \\
\text { dicari. }\end{array}$ & 1 & 9 & 25 & 26 & 2 & 3.30 \\
\hline 3 & $\begin{array}{l}\text { Cara } \\
\text { penggunaan } \\
\text { aplikasi } \\
\text { LAPOR } \\
\text { mudah untuk } \\
\text { diikuti. }\end{array}$ & 0 & 0 & 30 & 30 & 3 & 3.57 \\
\hline 4 & $\begin{array}{l}\text { Saya belum } \\
\text { menemui } \\
\text { kesulitan } \\
\text { berarti } \\
\text { selama } \\
\text { meng- } \\
\text { gunakan } \\
\text { aplikasi } \\
\text { LAPOR. }\end{array}$ & 1 & 2 & 37 & 20 & 3 & 3.34 \\
\hline \multirow[t]{2}{*}{5} & $\begin{array}{l}\text { Saya akan } \\
\text { tetap meng- } \\
\text { gunakan } \\
\text { aplikasi } \\
\text { LAPOR } \\
\text { karena } \\
\text { mudah untuk } \\
\text { digunakan. }\end{array}$ & 1 & 5 & 33 & 17 & 7 & 3.38 \\
\hline & $\begin{array}{l}\text { Keseluruhan } \\
\text { Kemudahan } \\
\text { Penggunaan }\end{array}$ & 3 & 18 & 154 & 120 & 20 & 3.43 \\
\hline
\end{tabular}

\section{Manfaat Penggunaan Program LAPOR}

Bagian ini mengevaluasi manfaat penggunaan program LAPOR bagi masyarakat Bandung. Tabel 3 menunjukkan hasil analisa untuk manfaat penggunaan program LAPOR yang diukur dengan menggunakan 5 pernyataan. Setiap pernyataan diukur dengan 5 tingkat persetujuan, berdasarkan skala $1=$ sangat tidak setuju, $2=$ tidak setuju, $3=$ netral, $4=$ setuju, $5=$ sangat setuju.

Hasil analisa menunjukkan bahwa pengguna program LAPOR mempunyai tanggapan yang positif mengenai manfaat penggunaan program 
ini. Diantaranya, pengguna berpendapat bahwa 'aplikasi LAPOR akan meningkatkan kesejahteraan masyarakat kota Bandung' dengan rata-rata paling tinggi yaitu 3.92. Di ikuti dengan pendapat tentang 'aplikasi LAPOR menjadi dengan rata-rata 3.90, 'aplikasi LAPOR dapat menghubungkan pemerintah dan masyarakatnya' dengan rata-rata 3.82, 'aplikasi LAPOR akan tetap bermanfaat di masa depan' dengan rata-rata 3.73, dan 'aplikasi LAPOR akan meningkatkan kinerja Pemerintah Kota Bandung' dengan ratarata paling rendah yaitu 3.63. Secara keseluruhan, pengguna program LAPOR berpendapat bahwa program ini bermanfaat ketika di gunakan dengan rata-rata keseluruhan 3.80 .

Tabel 3. Manfaat Penggunaan Program LAPOR

\begin{tabular}{|c|c|c|c|c|c|c|c|}
\hline \multirow{2}{*}{ No } & \multirow{2}{*}{$\begin{array}{c}\text { Manfaat } \\
\text { Penggunaan }\end{array}$} & \multicolumn{5}{|c|}{ Tingkat Persetujuan } & \multirow{2}{*}{$\begin{array}{r}\text { Rata- } \\
\text { rata }\end{array}$} \\
\hline & & 1 & 2 & 3 & 4 & 5 & \\
\hline 1 & $\begin{array}{l}\text { Aplikasi } \\
\text { LAPOR } \\
\text { dapat meng- } \\
\text { hubungkan } \\
\text { pemerintah dan } \\
\text { masyarakat } \\
\text { nya. }\end{array}$ & 1 & 1 & 15 & 37 & 9 & 3.82 \\
\hline 2 & $\begin{array}{l}\text { Aplikasi } \\
\text { LAPOR } \\
\text { menjadi sarana } \\
\text { penyalur } \\
\text { keluh kesah } \\
\text { masyarakat. }\end{array}$ & 0 & 0 & 16 & 37 & 10 & 3.90 \\
\hline 3 & $\begin{array}{l}\text { Aplikasi } \\
\text { LAPOR akan } \\
\text { meningkatkan } \\
\text { kinerja } \\
\text { pemerintah } \\
\text { kota Bandung. }\end{array}$ & 0 & 3 & 24 & 29 & 7 & 3.63 \\
\hline 4 & $\begin{array}{l}\text { Aplikasi } \\
\text { LAPOR akan } \\
\text { mening-katkan } \\
\text { kesejahteraan } \\
\text { masyarakat } \\
\text { kota Bandung. }\end{array}$ & 3 & 33 & 21 & 5 & 1 & 3.92 \\
\hline \multirow[t]{2}{*}{5} & $\begin{array}{l}\text { Aplikasi } \\
\text { LAPOR akan } \\
\text { tetap ber- } \\
\text { manfaat di } \\
\text { masa depan. }\end{array}$ & 0 & 2 & 22 & 30 & 9 & 3.73 \\
\hline & $\begin{array}{l}\text { Keseluruhan } \\
\text { Manfaat } \\
\text { Penggunaan }\end{array}$ & 4 & 39 & 98 & 138 & 36 & 3.80 \\
\hline
\end{tabular}

\section{Sikap Pengguna Terhadap Program LAPOR}

Bagian ini mengevaluasi sikap pengguna terhadap program LAPOR bagi masyarakat Bandung. Tabel 4 menunjukkan hasil analisa untuk sikap pengguna terhadap program
LAPOR yang diukur dengan menggunakan 5 pernyataan. Setiap pernyataan diukur dengan 5 tingkat persetujuan, berdasarkan skala $1=$ sangat tidak setuju, $2=$ tidak setuju, $3=$ netral, $4=$ setuju, $5=$ sangat setuju.

Hasil analisa menunjukkan bahwa pengguna program LAPOR mempunyai sikap yang positif terhadap program ini. Diantaranya, pengguna menyatakan bahwa 'saya mendukung tujuan pemerintah untuk membuat aplikasi LAPOR' dengan rata-rata paling tinggi yaitu 3.95. Di ikuti dengan pendapat tentang 'saya merasa aplikasi LAPOR adalah sarana yang dibutuhkan masyarakat saat ini' dengan rata-rata 3.92, 'saya akan tetap mendukung kelanjutan dari program LAPOR' dengan rata-rata 3.88 , 'saya yakin aplikasi LAPOR akan semakin membaik' dengan rata-rata 3.79, dan 'saya membutuhkan LAPOR untuk menyalurkan aspirasi saya' dengan rata-rata paling rendah yaitu 3.63. Secara keseluruhan, pengguna program LAPOR mempunyai sikap yang positif terhadap program ini dengan rata-rata skor keseluruhan 3.83.

Tabel 4. Sikap Pengguna Terhadap Program LAPOR

\begin{tabular}{|c|c|c|c|c|c|c|c|}
\hline \multirow[t]{2}{*}{ No } & \multirow[t]{2}{*}{ Sikap Pengguna } & \multicolumn{5}{|c|}{ Tingkat Persetujuan } & \multirow{2}{*}{$\begin{array}{c}\text { Rata- } \\
\text { rata }\end{array}$} \\
\hline & & 1 & 2 & 3 & 4 & 5 & \\
\hline 1 & $\begin{array}{l}\text { Saya mendukung } \\
\text { tujuan } \\
\text { pemerintah } \\
\text { untuk membuat } \\
\text { aplikasi LAPOR. }\end{array}$ & 0 & 1 & 14 & 35 & 13 & 3.95 \\
\hline 2 & $\begin{array}{l}\text { Saya merasa } \\
\text { aplikasi LAPOR } \\
\text { adalah sarana } \\
\text { yang dibutuhkan } \\
\text { masyarakat saat } \\
\text { ini. }\end{array}$ & 0 & 2 & 13 & 36 & 12 & 3.92 \\
\hline 3 & $\begin{array}{l}\text { Saya } \\
\text { membutuhkan } \\
\text { LAPOR untuk } \\
\text { menyalurkan } \\
\text { aspirasi saya. }\end{array}$ & 0 & 3 & 24 & 29 & 7 & 3.63 \\
\hline 4 & $\begin{array}{l}\text { Saya yakin } \\
\text { aplikasi LAPOR } \\
\text { akan semakin } \\
\text { membaik. }\end{array}$ & 0 & 1 & 22 & 29 & 11 & 3.79 \\
\hline \multirow[t]{2}{*}{5} & $\begin{array}{l}\text { Saya akan tetap } \\
\text { mendukung } \\
\text { kelanjutan } \\
\text { dari program } \\
\text { LAPOR. }\end{array}$ & 0 & 1 & 18 & 31 & 13 & 3.88 \\
\hline & $\begin{array}{l}\text { Keseluruhan } \\
\text { Sikap Pengguna }\end{array}$ & 0 & 8 & 91 & 160 & 56 & 3.83 \\
\hline
\end{tabular}

Sumber : Diolah oleh Peneliti (2016) 


\section{Tingkat Penggunaan Program LAPOR}

Penggunaan program LAPOR bagi masyarakat Bandung. Tabel 5 menunjukkan hasil analisa untuk tingkat penggunaan program LAPOR yang diukur dengan menggunakan 5 pernyataan. Setiap pernyataan diukur dengan 5 tingkat persetujuan, berdasarkan skala $1=$ sangat tidak setuju, $2=$ tidak setuju, $3=$ netral, $4=$ setuju, $5=$ sangat setuju.

Hasil analisa menunjukkan bahwa pengguna program LAPOR mempunyai tingkat penggunaan yang tinggi untuk program ini. Diantaranya, pengguna menyatakan bahwa 'saya tidak pernah menyalahgunakan aplikasi LAPOR' dengan rata-rata paling tinggi yaitu 3.85. Di ikuti dengan pendapat tentang 'saya akan tetap menggunakan aplikasi LAPOR di masa hadapan' dengan rata-rata 3.63, 'saya menggunakan aplikasi lapor untuk kepentingan umum' dengan rata-rata 3.44, 'saya selalu menggunakan aplikasi LAPOR untuk hal yang sesuai dengan fungsinya' dengan rata-rata 3.25 , dan 'saya selalu menggunakan aplikasi LAPOR setiap kali menemui hal yang ingin disampaikan kepada pemkot' dengan ratarata paling rendah yaitu 2.85 . Secara keseluruhan, pengguna program LAPOR mempunyai tingkat penggunaan yang tinggi untuk program ini dengan rata-rata keseluruhan 3.40.

Tabel 5. Tingkat Penggunaan Program LAPOR

\begin{tabular}{|c|c|c|c|c|c|c|c|}
\hline \multirow[t]{2}{*}{ No } & \multirow{2}{*}{$\begin{array}{c}\text { Tingkat } \\
\text { Penggunaan }\end{array}$} & \multicolumn{5}{|c|}{ Tingkat Persetujuan } & \multirow{2}{*}{$\begin{array}{c}\text { Rata- } \\
\text { rata }\end{array}$} \\
\hline & & 1 & 2 & 3 & 4 & 5 & \\
\hline 1 & $\begin{array}{l}\text { Saya selalu } \\
\text { menggunakan } \\
\text { aplikasi LAPOR } \\
\text { setiap kali } \\
\text { menemui hal yang } \\
\text { ingin disampaikan } \\
\text { kepada pemkot. }\end{array}$ & 2 & 22 & 25 & 11 & 3 & 2.85 \\
\hline 2 & $\begin{array}{l}\text { Saya selalu } \\
\text { menggunakan } \\
\text { aplikasi LAPOR } \\
\text { untuk hal yang } \\
\text { sesuai dengan } \\
\text { fungsinya. }\end{array}$ & 1 & 10 & 27 & 22 & 3 & 3.25 \\
\hline 3 & $\begin{array}{l}\text { Saya menggunakan } \\
\text { aplikasi lapor } \\
\text { untuk kepentingan } \\
\text { umum. }\end{array}$ & 1 & 4 & 28 & 26 & 4 & 3.44 \\
\hline 4 & $\begin{array}{l}\text { Saya tidak pernah } \\
\text { menyalahgunakan } \\
\text { aplikasi LAPOR. }\end{array}$ & 1 & 4 & 10 & 36 & 12 & 3.85 \\
\hline \multirow[t]{2}{*}{5} & $\begin{array}{l}\text { Saya akan tetap } \\
\text { menggunakan } \\
\text { aplikasi LAPOR di } \\
\text { masa hadapan. }\end{array}$ & 0 & 3 & 26 & 25 & 9 & 3.63 \\
\hline & $\begin{array}{l}\text { Keseluruhan } \\
\text { Tingkat } \\
\text { Penggunaan }\end{array}$ & 5 & 43 & 116 & 120 & 31 & 3.40 \\
\hline
\end{tabular}

\section{Kinerja Operator Program LAPOR}

Bagian ini mengevaluasi kinerja operator program LAPOR bagi masyarakat Bandung. Tabel 6 menunjukkan hasil analisa kinerja operator program LAPOR yang diukur dengan menggunakan 4 pernyataan. Setiap pernyataan diukur dengan 5 tingkat persetujuan, berdasarkan skala $1=$ =sangat tidak setuju, $2=$ tidak setuju, $3=$ netral, $4=$ setuju, $5=$ sangat setuju.

Hasil analisa menunjukkan bahwa pengguna program LAPOR mempunyai tanggapan yang positif terhadap kinerja operator program ini. Diantaranya, pengguna menyatakan bahwa 'petugas LAPOR memberi informasi tentang status penyelesaian keluhan atau pertanyaan' dengan rata-rata paling tinggi yaitu 3.49. Di ikuti dengan pendapat tentang 'keluhan/pertanyaan dapat dieselesaikan atau di tindaklanjuti dengan baik' dengan rata-rata 3.42, 'jawaban yang diberikan jelas dan memberikan solusi yang konkrit' dengan rata-rata 3.20 , dan 'respon terhadap keluhan/pertanyaan dilakukan dengan cepat' dengan rata-rata paling rendah yaitu 3.14. Secara keseluruhan, pengguna program LAPOR mempunyai tanggapan yang positif terhadap kinerja operator program ini dengan rata-rata keseluruhan 3.31.

Tabel 6. Kinerja Operator Program LAPOR

\begin{tabular}{|c|c|c|c|c|c|c|c|}
\hline \multirow{2}{*}{ No } & \multirow{2}{*}{ Kinerja Operator } & \multicolumn{5}{|c|}{ Tingkat Persetujuan } & \multirow{2}{*}{$\begin{array}{l}\text { Rata- } \\
\text { rata }\end{array}$} \\
\hline & & 1 & 2 & 3 & 4 & 5 & \\
\hline 1 & $\begin{array}{l}\text { Respon terhadap } \\
\text { keluhan/pertanyaan } \\
\text { dilakukan dengan } \\
\text { cepat. }\end{array}$ & 1 & 9 & 34 & 18 & 1 & 3.14 \\
\hline 2 & $\begin{array}{l}\text { Jawaban yang } \\
\text { diberikan jelas dan } \\
\text { memberikan solusi } \\
\text { yang konkrit. }\end{array}$ & 1 & 3 & 43 & 14 & 2 & 3.20 \\
\hline 3 & $\begin{array}{l}\text { Keluhan/pertanyaan } \\
\text { dapat dieselesaikan } \\
\text { atau di tindaklanjuti } \\
\text { dengan baik. }\end{array}$ & 1 & 1 & 33 & 26 & 2 & 3.42 \\
\hline \multirow[t]{2}{*}{4} & $\begin{array}{l}\text { Petugas LAPOR } \\
\text { memberi informasi } \\
\text { tentang status } \\
\text { penyelesaian } \\
\text { keluhan atau } \\
\text { pertanyaan. }\end{array}$ & 1 & 2 & 29 & 27 & 4 & 3.49 \\
\hline & $\begin{array}{l}\text { Keseluruhan } \\
\text { Kinerja Operator }\end{array}$ & 4 & 15 & 139 & 85 & 9 & 3.31 \\
\hline
\end{tabular}

Sumber : Diolah oleh Peneliti (2016)

\section{HASIL DAN PEMBAHASAN}

Pada bagian ini akan dianalisis hasil penelitian pada bagian sebelumnya. Analisis mengacu pada hasil yang diperoleh dari tiga 
rumusan masalah besar dalam penelitian ini. Terdapat tiga hal yang dianalisis, yaitu (1) Tingkat partisipasi penggunaan LAPOR oleh masyarakat Kota Bandung, (2) Faktor-faktor yang mempengaruhi partisipasi penggunaan LAPOR, dan (3) Kinerja Operator Program LAPOR.

\section{Tingkat Partisipasi Penggunaan LAPOR oleh Masyarakat Kota Bandung}

Partisipasi adalah hal yang penting dalam kehidupan demokrasi. Dalam menjalankan roda pembangunan pemerintah perlu mendapatkan adanya masukan dari masyarakat, dan hal ini dapat di dorong bila pemerintah kemudian menyediakan sarana partisipasi bagi masyarakat untuk dapat menyuarakan aspirasinya. Banyak instrument yang bisa digunakan untuk menampung aspirasi masyarakat, salah satunya LAPOR. Dalam observasi peneliti, partisipasi masyarakat Kota Bandung dalam menggunakan aplikasi LAPOR belum maksimal.

Masyarakat Kota Bandung yang tidak mengetahui LAPOR tergolong besar, yaitu 36,1\%. Sisanya $63,9 \%$ mengetahui LAPOR, namun hanya $35 \%$ yang berpartisipasi menggunakannya. Artinya terdapat $75 \%$ masyarakat yang belum berpartisipasimenggunakanLAPOR(HasilPerhitungan Kuantitatif, 2016). Hasil ini sangat sejalan dengan penelitian sebelumnya tentang LAPOR, yakni hingga Juni 2015 yang menggunakan aplikasi LAPOR hanya $0,3 \%$ dari total warga bandung (Atnan dan Imran, 2015). Kondisi ini menunjukkan bahwa mayoritas masyarakat Kota Bandung sesungguhnya belum mengenal dan memanfaatkan aplikasi LAPOR, padahal aplikasi ini sudah digunakan sejak bulan November 2013.

Masyarakat yang tidak mengetahui aplikasi LAPOR berada dalam rentang usia 20-30 tahun, dimana jumlahnya sebanyak $55 \%$ dari total responden yang tidak menge-tahui aplikasi LAPOR. Dari sejumlah itu, pendidikan akhirnya rata-rata hanya lulus SMA saja. Kondisi ini menunjukkan bahwa pemerintah yang dalam hal ini Diskominfo Kota Bandung terutama desk LAPOR perlu memperhatikan sosialisai utuk komunitas ini. Sangat berbeda dengan kondisi kelompok mahasiswa, dimana ratarata mereka mengetahui LAPOR dan bahkan memanfaatkannya.

Kondisi ditas bisa terjadi karena lemah pada aspek sosialisasi. Berdasarkan pengakuan penanggungjawab LAPOR Ibu Peni Setiati bahwa sejauh ini Diskominfo sudah mensosialisasikan
LAPOR melalui media konvensional yakni presentasi di kantor-kantor kecamatan se-Kota Bandung, melalui Media Massa yakni Radio serta menggunakan media sosial berupa Facebook, Twitter, dan Website (Atnan dan Ayub, 2015). Sosialisasi tersebut belum maksimal di lakukan. Untuk sosialisasi konsvensional, kelemahannya adalah tidak konsisten dan masih kurang masif. Untuk media massa, kelemahannya pilihan media yang kurang tepat karena hanya menggunakan Sonata Radio yang nota bene jangkauannya masih sangat terbatas.

Dari sisi media, seharusnya media yang digunakan adalah media yang punya daya jangkau luas. Pilihan ini menjadi rasional karena, penelitian ini menunjukkan bahwa $51,3 \%$ masyarakat mengetahui LAPOR dari media terutama media massa. Artinya preferensi masyarakat Kota Bandung mengetahui LAPOR melalui media massa. Oleh karena itu, pilihan medianya haruslah tepat. Media-media yang punya jangkauan luas seperti iklan melalui TV nasional, atau Koran Nasional, termaksud Koran Lokal yang menjadi sumber informasi masyarakat Kota Bandung. Untuk koran lokal yang bisa menjadi pilihan seperti Pikiran Rakyat.

Upaya diatas masih belum cukup. Perlu upaya lain untuk terus menjaga konsistensi sosialisasi. Pilihannya adalah konsisiten melakukan sosialisasi konvensional melalui kantorkantor kecamatan dan kelurahan. Minimal poster, banner tentang LAPOR terus terjaga da terpasang di setiap kantor Kecamatan dan Kelurahan. Tujuannya agar masyarakat yang berurusan di kantor kecamatan atau kelurahan terus terterpa oleh informasi tentang LAPOR. Hal lain yang bisa dilakukan adalah memasang informasi LAPOR melalui media reklame di titik-titik keramaian Kota Bandung. Atau barangkali bisa dipasang ketika masuk Kota Bandung melalui pintu-pintu tol utama. Hal ini memungkinkan setiap orang yang akan memasuki atau meninggakan Kota Bandung akan selalu terterpa informasi soal LAPOR.

\section{Faktor-faktor yang Mempengaruhi Parti- sipasi Masyarakat Kota Bandung dalam Penggunaan LAPOR}

Selain mengukur tingkat setiap variabel yang digunakan, penelitian ini juga bertujuan untuk mengetahui hubungan antara setiap variabel sesuai dengan kerangka konsepsual penelitian dibawah ini: 


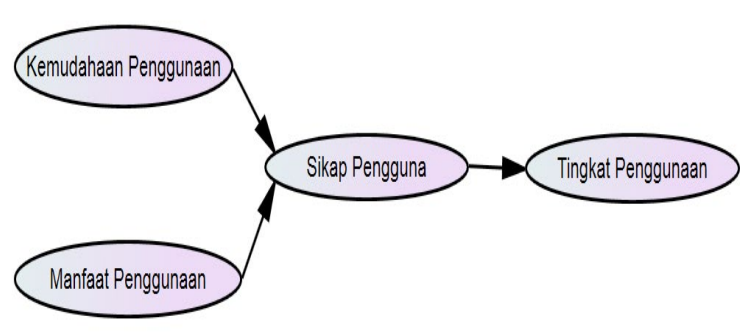

Sumber : Diolah oleh Peneliti, 2016.

Gambar 1. Kerangka Konsepsual Penelitian

Melalui kerangka konsepsual diatas, penelitian ini berhipotesa bahwa Kemudahaan Penggunaan (Ease of Use) dan Manfaat Penggunaan (Usefulness) mempunyai korelasi langsung dengan Sikap Pengguna (Attitude) yang pada akhirnya akan mempengaruhi Tingkat Penggunaan (Usage) Program LAPOR. Untuk menguji hipotesis tersebut, maka penelitian ini menerapkan analisis Bivariate Correlation dan Multiple Regression.

\section{Hubungan Antara Setiap Faktor}

HasilanalisaBivariateCorrelationmendapati bahwa terdapat hubungan yang signifikan dan cukup kuat antara Kemudahan Penggunaan dan Sikap Pengguna dengan nilai korelasi 0.535. Nilai ini juga menunjukan hubungan yang yang positif antara kedua variable yang berarti bahwa semakin mudah sebuah teknologi untuk digunakan maka semakin positif sikap para pengguna terhadap teknologi tersebut. Hasil analisa juga menunjukan terdapatnya hubungan yang signifikan dan cukup kuat antara Manfaat Penggunaan dan Sikap Pengguna $(\mathrm{r}=0.412)$. Nilai korelasi positif juga memberikan indikasi bahwa semakin tingginya manfaat sebuah teknologi maka semakin positif juga tanggapan para pengguna terhadap teknologi tersebut. Selanjutnya, hasil analisa korelasi bivariat menunjukan bahwa terdapat hubungan yang signifikan dan positif antara Sikap Pengguna dan Tingkat Penggunaan dengan nilai korelasi 0.412. Nilai ini juga memberikan indikasi bahwa semakin baik tanggapan pengguna terhadap sebuah teknologi maka semakin tinggi tingkat penggunaan teknologi tersebut.

\section{Faktor Utama Penentu Sikap Pengguna Prog- ram LAPOR}

Untuk mengetahui faktor utama penentu sikap sikap pengguna programLAPOR, penelitian ini menggunakan analisis Multiple Regression. Hasil analisa mendapati bahwa Kemudahan Penggunaan $(B=0.465)$ merupakan faktor yang lebih berpengaruh terhadap Sikap Pengguna saat dibandingkan dengan Manfaat Penggunaan $(\mathrm{B}=0.154)$. Hal ini memberikan indikasi bahwa calon pengguna lebih memen-tingkan kemudahan penggunaan sebuah teknologi baru dibandingkan manfaat dari teknologi tersebut.

\section{Kinerja Operator Program LAPOR}

Untuk mendalami temuan kuantitatif penelitian ini, peneliti juga memberikan 3 pertanyaan terbuka dalam upaya memberikan evaluasi yang lebih mendalam tentang Program Lapor dari sudut pandang masyarakat sebagai pengguna. Hasil evaluasi data kualitatif (Tabel 3.5) mendapati bahwa sebagian besar masyarakat kota Bandung merasa bahwa sosialisasi aplikasi program LAPOR sudah sudah cukup bagus (54.5\%). Walaupun begitu, beberapa pendapat menyatakan bahwa masih banyak masyarakat yang belum mengetahui mengenai program ini. Mereka merasa bahwa upaya sosialisasi masih belum menjangkau beberapa daerah-daerah tertentu, terutama dibagian kelurahan. Selain itu, masyarakat juga merasa bahwa sosialisasi program LAPOR tidak intens sehingga perlu adanya keberlanjutan dari Pemerintah Kota Bandung.

Tabel 7. Pendapat Responden tentang Sosialisasi Aplikasi LAPOR di Kota Bandung.

\begin{tabular}{lc}
\hline \multicolumn{1}{c}{ Kategori Saran } & Jumlah \\
\hline Sosialisasi Perlu Ditingkatkan & $26(29.5 \%)$ \\
$\begin{array}{l}\text { Lebih cepat dan tanggap dalam } \\
\text { merespon dan menindaklanjuti } \\
\text { laporan }\end{array}$ & $22(25.0 \%)$ \\
$\begin{array}{l}\text { Perbaikan sistem agar tidak Eror } \\
\text { Penerangan tentang cara } \\
\text { penggunaan }\end{array}$ & $8(9.1 \%)$ \\
$\begin{array}{l}\text { Tingkatkan interaksi dengan } \\
\text { pengguna untuk kritik dan saran } \\
\text { perbaikan aplikasi }\end{array}$ & $8(9.1 \%)$ \\
\hline
\end{tabular}

Sumber : Diolah oleh Peneliti, 2016.

Tabel 8. Pendapat Responden tentang Pemenuhan Tujuan Aplikasi LAPOR

\begin{tabular}{|c|c|}
\hline \multicolumn{2}{|c|}{ Kategori } \\
\hline Memenuhi & Tidak Memenuhi \\
\hline $41(46.6 \%)$ & $26(29.5 \%)$ \\
\hline \multicolumn{2}{|c|}{ Alasan } \\
\hline Memenuhi & Tidak Memenuhi \\
\hline $\begin{array}{l}\text { - Keluhan masyarakat } \\
\text { langsung tersalurkan } \\
\text { - Menampung aspirasi warga } \\
\text { Bandung } \\
\text { - Menjadi saluran keluhan } \\
\text { dan aduan } \\
\text { - Menampung aspirasi } \\
\text { masyarakat }\end{array}$ & $\begin{array}{l}\text { - Laporan kadang tidak } \\
\text { ditindaklanjuti } \\
\text { - Respon atas pengaduan } \\
\text { kurang cepat } \\
\text { - Penyelesaian pengaduan } \\
\text { masyarakat belum maksimal }\end{array}$ \\
\hline
\end{tabular}


Tabel 9. Saran Perbaikan untuk Mewujudkan Efisiensi Aplikasi LAPOR

\begin{tabular}{|c|c|c|}
\hline \multicolumn{3}{|c|}{ Kategori } \\
\hline Bagus & Cukup Bagus & Kurang \\
\hline $12(13.6 \%)$ & $36(40.9 \%)$ & $19(21.6 \%)$ \\
\hline \multicolumn{3}{|c|}{ Alasan } \\
\hline Bagus & Cukup Bagus & Kurang \\
\hline $\begin{array}{l}\text { - Mendapat } \\
\text { informasi } \\
\text { dari kantor } \\
\text { kelurahan }\end{array}$ & $\begin{array}{l}\text { - } \text { Belum } \\
\text { menjangkau } \\
\text { seluruh } \\
\text { masyarakat } \\
\text { Kota Bandung } \\
\text { - Sosialisasi } \\
\text { tidak menarik } \\
\text { - Masyarakat } \\
\text { tidak } \\
\text { memahami } \\
\text { cara } \\
\text { penggunaan }\end{array}$ & $\begin{array}{l}\text { - Masih banyak } \\
\text { masyarakat } \\
\text { yang belum } \\
\text { mengetahui } \\
\text { LAPOR } \\
\text { - Sosialisasi dari } \\
\text { pihak kelurahan } \\
\text { masih kurang } \\
\text { - Tidak } \\
\text { menjangkau } \\
\text { daerah-daerah } \\
\text { tertentu } \\
\text { - Sosialisasi } \\
\text { tidak intens } \\
\text { (berkelanjutan) }\end{array}$ \\
\hline
\end{tabular}

Sumber : Diolah oleh Peneliti, 2016.

\section{SIMPULAN}

Berdasarkan hasil penelitian dan pembahasan, maka terdapat beberapa kesimpulan, sebagai berikut (1) Masyarakat Kota Bandung masih banyak yang belum mengetahui dan berpartisipasi menggunakan aplikasi LAPOR, yakni yang belum mengetahui sebesar $36,1 \%$ dan yang belum berpartisipasi menggunakannya sebesar $75 \%$, (2) Faktor yang paling signifikan mempengaruhi partisipasi penggunaan aplikasi LAPOR adalah karena kemudahannya, bukan karena manfaatnya, dan (3) Kinerja Operator LAPOR sudah cukup baik, dimana berada pada posisi 3,1 dari dari skala 5, namun memiliki kelehaman terutama dari sisi kecepatan merespon pengaduan dan kesigapan dalam menindaklanjuti setiap pengaduan.

Berdasarkan kesimpulan penelitian, terdapat beberapa saran, yaitu (1) Sosialisasi perlu ditingkatkan terutama pada masyarakat yang pendidikannya hanya lulus SMA. Hal lain yang perlu dilakukan adalah konsistensi sosialisasi di kantor-kantor kecamatan dan kelurahan, (2) Dalam proses sosialisasi, yang perlu ditonjolkan adalah aspek kemudahan aplikasi LAPOR karena rata-rata masyarakat Kota Bandung sangat mengedepankan aspek kemudahan penggunaan, dan (3) Operator LAPOR memperbaiki kinerjanya terutama pada aspek kecepatan dan kemampuan penyelesaian pengaduan masyarakat. Dalam hal ini update informasi status penyelesaian pengaduan perlu terus dilakukan agar masyarakat selalu mengetahui kondisi penyelesaian pengaduannya.

\section{DAFTAR PUSTAKA}

Ajzen, I., \& Fishbein, M. (1980). Understanding Attitudes and Predicting Social Behavior. Englewood Cliffs, NJ: Prentice-Hall.

Ancok, D. (1993). Teknik Penyusunan Skala Pengukur. Yogyakarta: Graha Ilmu.

Atnan, N. \& Imran, A.I. (2015). Strategi Sosialisasi dan Pendekatan Komunikasi DISKOMINFO dalam Pengelolaan Aplikasi LAPOR di Kota Bandung. Prosiding COMNEWS: Universitas Multi Media Tangerang.

Bungin, B. (2010). Penelitian Kualitatif. Jakarta: Kencana Prenada Media Group.

BPS Kota Bandung. (2014). Kota Bandung Dalam Angka Tahun 2014. Bandung: BPS Kota Bandung.

Cangara, H. (2014). Perencanaan dan Strategi Komunikasi. Depok: PT Raja Grafindo Persada.

Creswell, J.W. (2010). Research Design, Pendekatan Kualitatif, Kuantitatif dan Mixed. Yogyakarta: Pustaka Pelajar.

Davis, F.D. (1986). A Technology Acceptance Model for Empirically Testing New End-User Information Systems: Theory Andresults. Doctoral dissertation. Cambridge, MA: MIT Sloan School of Management.

Davis, F. D., Bagozzi, R. P., \& Warshaw, P. R. (1989). User Acceptance of Computer Technology: A Comparison of Two Theoretical Models. Management Science, 35 (8), 982-100.

Fishbein, M. \& Ajzen, I. (1975). Belief, Attitude, Intention and Behavior: An Introduction to Theory and Research, Reading. M.A: Addison-Wesley.

Jati, W.R. (2016). Cyberspace, Internet, dan Ruang Publik Baru; Aktivisme Online Politik Kelas Menengah Indonesia. Jurnal Pemikiran Sosiologi, 3 (1), 17-29.

Kriyantono, R. (2012). Teknik Praktis Riset Komunikasi. Jakarta: Kencana Prenada Media Group. 
LAPOR. (2015). Sumber: https://www.lapor. go.id/statistik/ (diakses tanggal 8 Juni 2015).

Mathieson, K. (1991). Predicting User Intentions: Comparing the Technology Acceptance Model with the Theory of Planned Behavior. Information Systems Research, 2 (2), 173-191.

Miles, M.B., \& Huberman, M.A. (1984). Qualitative Data Analysis; A Sourccebook of New Methods. London: SAGE Publications.

Praveena, K., \& Thomas, S. (2014). Continuance Intention to Use Facebook: A Study of Perceived Enjoyment and TAM. Bonfring International Journal of Industrial Engineering and Management Science, 4 (1), 5-10.

Purwanto, E.A., \& Sulistyostuti, D.R. (2007). Metode Penelitian Kuantitatif. Yogyakarta: Gaya Media.

Purworini, D. (2014). Model Informasi Publik di Era Media Sosial: Kajian Grounded Teori di Pemda Sukoharjo. Jurnal Komuniti, 4 (1), 3-14. DOI: https://doi.org/10.23917/ komuniti.v6il.2929.
Setiawan, H., \& Santoso, P. (2013). Model Optimalisasi Peluang Pemanfaatan MediaJejaring Sosial dalam Implementasi E-Governance di Indonesia. Semnas Informatika, UPN Veteran Yogyakarta.

Sugiyono. (2001). Metode Penelitian Administrasi. Bandung: CV ALFABETA.

Semiocast. (July 30th, 2012). "Twitter reaches half a billion accounts. More than 140 millions in the U.S. - Geolocation analysis of Twitter accounts and tweets by Semiocast." Sumber: https://semiocast. com/en/publications/2012_07_30 Twitter reaches half a billion accounts $140 \mathrm{~m}$ in the US ${ }^{-}$(diakses tanggal $\overline{10}$ Juni $\overline{20} \overline{15}$ ).

Tsai, C.M., Huang, Y.T., \& Hsieh, J.L. (2011). Taiwanese Facebook Users' Motivation and the Access of Information Technology. National Science Council, HCII 2011, CCIS.

Winarko, B., \& Mahadewi, L. (2013). Tinjauan Beberapa Model Teori Dasar Adopsi Teknologi Baru. Jurnal Sampoerna School of Business, 3 (4), 5-9. 